Moritz Pieper $\star$

Martijn Lak $k^{\star \star}$

\title{
The End of Transatlanticism? EU Security and Defence Policies and the 'Strategic Autonomy' Debate from a Historical and Contemporary Perspective
}

\begin{abstract}
This article examines whether calls for European 'strategic autonomy' in response to Trump's rhetoric are qualitatively different from earlier disagreements in US-EU relations. By doing so, it re-assesses Geir Lundestad's concept of "Empire by Invitation" to illustrate constraints for the development of such an autonomy especially in defence affairs. We argue that the US's involvement in European defence affairs was never an invitation to 'empire', as the invitational aspect was based on consent. A process has been accelerated by the Trump presidency whereby this consent has shifted towards strategic estrangement. However, the article argues that the reactive and intergovernmental nature of EU foreign and security policy continues to hamper more autonomous policy planning in CSDP matters - different readings about cyclical disruptions in EU-US relations notwithstanding. The article finally discusses how the introduction of new CSDP mechanisms impacts on this debate.
\end{abstract}

Keywords: Transatlanticism, Strategic Autonomy, CSDP, EU-US Relations

\footnotetext{
* Moritz Pieper - German Institute for International and Security Affairs, Berlin, e-mail: moritz.pieper@swp-berlin.org, ORCID: 0000-0003-3915-5424.

${ }^{\star \star}$ Martijn Lak - The Hague University of Applies Sciences and the Erasmus School of History, Culture and Communication, e-mail: m.lak@hhs.nl, ORCID: 0000-0003-4911-3527.
} 


\section{Introduction}

On 26th September 2017, French President Emmanuel Macron delivered a speech in which he laid out his visions for the future of European integration. One of the more controversial of his proposals was the call for a common European intervention force. "At the beginning of the next decade, Europe needs to establish a common intervention force, a common defence budget and a common doctrine for action," he said. ${ }^{1}$ In an address to the European Parliament in November 2018, German Chancellor Angela Merkel took up Macron's earlier proposal of a European intervention force and similarly spoke of the need to create a "real European army" some day. ${ }^{2}$ In her Trudering speech in 2017, Merkel had concluded that the "times in which we could completely rely on others are somewhat over". ${ }^{3}$ The responses to these suggestions from both opponents and supporters were reminiscent of reactions to proposals for common European defence structures ever since the idea first came up in the 1950s.

Those in favour of consolidated defence capabilities at a European level have always claimed that if Europe wants to play a more dominant role on the global stage, it needs its own army and should become less dependent on NATO and, by implication, the United States. The arrival of a seemingly unpredictable president in the White House in 2016 has precipitated these debates, as this article will show. The introduction of a "Permanent Structured Cooperation" (PESCO) in the EU's Common Security and Defence Policy in November 2017 has therefore been hailed as a timely and appropriate step towards a more enhanced defence autonomy of the European Union. Still, opponents see a common European army (for which mechanisms such as PESCO ostensibly serve as Trojan Horses) as the creation of an opponent to NATO, exposing different national views amongst member states on this issue.

Against the background of the discursive reiteration of the need to achieve "strategic autonomy" in the wake of the current transatlantic rift,

${ }^{1}$ E. Macron, Speech at Sorbonne University, 26 September 2017, http://international. blogs.ouest-france.fr/archive/2017/09/29/macron-sorbonne-verbatim-europe-18583.html (access 10.07.2018).

2 A. Merkel, Rede von Bundeskanzlerin Merkel vor dem Europäischen Parlament am 13. November 2018 in Straßburg, https:/www.bundeskanzlerin.de/bkin-de/aktuelles/redevon-bundeskanzlerin-merkel-vor-dem-europaeischen-parlament-am-13-november-2018in-strassburg-1549538 (access 24.08.2019).

3 B. Ulrich, Ihr langer Weg nach Trudering, "ZEIT online", 31 May 2017, https:// www.zeit.de/2017/23/angela-merkel-transatlantische-beziehungen-kritik-donald-trump (access 21.11.2017). 
this article aims to shed light on whether or not such calls for 'strategic autonomy' are qualitatively different from earlier such ambitions in light of transatlantic ambiguities. Calls for "strategic autonomy" have been an almost permanent feature of the fluctuating EU-US relationship and have inspired a burgeoning literature. ${ }^{4}$ The term is as ubiquitous as it is vague, and is here defined as a comprehensive ability to enact foreign and security policies that are independent institutionally and politically. ${ }^{5}$ Importantly, "strategic autonomy" thus defined goes beyond defence arrangements and includes policy domains with a "foreign" dimension such as trade, diplomacy, or energy. This article, however, argues that it is especially in the defence realm that recurring trends in US-EU relations have been impediments to the realisation of a "strategic autonomy". The aim of the article is thus twofold: To assess the nature of the EU's "strategic autonomy" debate following the election of Donald Trump from a historical perspective, and to examine in-built constraints that complicate the materialisation of such an autonomy. Doing so, we re-examine Geir Lundestad's "Empire by Invitation" as an illustration of the constraints US foreign policy has imposed on the evolution of the EU as a security actor. This concept has been a pet theme for scholars seeking to explain the relationship between the US and Western Europe during the Cold War. The voluntary invitation extended on the part of Western Europe to the United States to establish a permanent military presence in Europe became the bedrock of military planning for much of the remainder of the emerging Cold War. It also constituted an umbrella that thwarted the development of any genuine European defence autonomy. After the end of the Cold War, therefore, a path dependency in transatlantic security arrangements made 'strategic autonomy' not only difficult institutionally, but unwanted politically.

The coming into being of this inadvertent empire is the subject of the first part of this article. Specifically, the article sheds light on how and why the existence of a US-dominated collective security organization (NATO) prevented the development of autonomous European defence

${ }^{4}$ S. Hoffmann, Discord in Community: The North Atlantic Area as a Partial International System, "International Organization", Vol. 17, No. 3/1963, pp. 521-549; G. Lundestad, The United States and Western Europe since 1945: from 'empire' by invitation to transatlantic drift, Oxford University Press, Oxford 2003; Defending Europe. The EU, NATO and the Quest for European Autonomy, eds. J. Howorth, J.T.S. Keeler, Palgrave Macmillan, Basingstoke 2003; M. Smith, Transatlantic security relations since the European security strategy: what role for the EU in its pursuit of strategic autonomy?, "Journal of European Integration", Vol. 40, No. 5/2018, pp. 605-620.

5 B. Lippert, N. von Ondarza, V. Perthes, European Strategic Autonomy. Actors, Issues, Conflicts of Interests, "SWP Research Paper” 4, March 2019. 
structures. Faced with an "Empire by Invitation", EU security actors have willingly given away agency under the banner of a "transatlantic alliance". The second part then traces the evolution of European defence structures in light of American scepticism regarding European "strategic autonomy" in the 1990s and 2000s and in a context in which the invitational aspect of the transatlantic defence order began to shift. US criticism of the European Security and Defence Identity in the 1990s tempered the development of European defence capabilities, while US criticism two decades later of European "free-riding" in security matters has accelerated it. At a structural level, however, we argue that the difference between "Atlanticist" member states and those in favour of an independent European security and defence coordination has not abated and continues to hamper more ambitious policy planning in CSDP matters. The final part sheds some light on how the introduction of new CSDP mechanisms and the UK's decision to leave the EU might impact on this observation. The 'Trump factor', as will be shown, operates rather at the level of official policy discourse, while transatlantic defence relations show a degree of continuity, which will impact on any future development towards 'strategic autonomy'.

\section{European Defence Policies after WWII: Keeping Germans down and Americans in}

When the guns fell silent in Europe in May 1945, a central question for the political future order on the Continent was that of Germany's future, ${ }^{6}$ and, as the definitive end of the wartime coalition gave rise to tensions with the Soviet Union, the limitation of a perceived Soviet expansion. The foundation of two Germanys, the Federal Republic of Germany and the German Democratic Republic on 23rd May and 7th October 1949 respectively, thus also cemented the division between the former wartime allies. Almost as soon as the FRG was established, the question of the rearmament of West Germany resurfaced. When the American minister of Foreign Affairs Dean Acheson in September 1950 initiated a discussion with the British and the French on West German rearmament within NATO, the French opposed it vehemently, as they saw NATO as "a stalking horse for the remilitarisation of Germany". ${ }^{7}$ To

${ }^{6}$ M. Lak, The Early Years of European Integration - German and Dutch Reactions to the Schuman Plan, in: Governance and Security Issues of the European Union. Challenges Ahead, eds. J. de Zwaan, M. Lak, A. Makinwa, P. Willems, T.M.C. Asser Press, The Hague 2016, p. 15.

7 T. Judt, Postwar. A History of Europe Since 1945, Pimlico, London 2005, pp. 243-244. 
Paris, the idea of West Germany joining NATO was a non-starter, and had to be avoided at all costs. ${ }^{8}$ The French feared that if West German troops were to become part of NATO, France could not control them; indeed, they would then come under American influence. ${ }^{9}$ If West Germany was to be rearmed, it should be done in a European framework instead of within NATO structures.

On 24th October 1950, French prime minister René Pleven therefore floated the idea of a European Defence Community in analogy to the Schuman Plan. ${ }^{10} \mathrm{He}$ suggested bringing small, national units under the leadership of a European minister of defence, accountable to a European parliament. ${ }^{11}$ Germany's growing economic strength would be put under the control of supranational European institutions, while its security potential would be multilateralised in a Western European context. ${ }^{12}$ Controlling Germany and containing Soviet influence became a policy of "dual containment". ${ }^{13}$

A "security community", Karl Deutsch wrote in 1957, was to come into being through "peaceful change" and the pooling of resources in a multinational context. ${ }^{14}$ In France, however, opinions about such a new European defence community were mixed. The Communists and Gaullists strongly opposed it. Public opinion was divided; polls showed "that 64 percent favoured European unity while 57 percent viewed the arming of German troops as a threat to France". ${ }^{15}$ The long negotiations annoyed the United States along with its Secretary of State, John Foster Dulles. Yet, he recognized that a landmark decision was in the making. During a closed session of the North Atlantic Council of 14 December 1953, he claimed that the EDC was a test of Western Europe's ability to bury past differences and build a peaceful future. ${ }^{16}$

8 Ibidem, p. 244.

9 G. Brunn, Die Europaïsche Einigung von 1945 bis heute, Bundeszentrale für politische Bildung, Bonn 2006, p. 90.

10 T. Judt, op. cit., p. 244.

11 G. Brunn, op. cit., pp. 345-346.

12 M. Segers, Nederland en de Europese integratie, in: De wereld volgens Nederland. Nederlandse buitenlandse politiek in historisch perspectief, eds. J. Pekelder, R. Raben, M. Segers, Boom, Amsterdam 2015, p. 91.

${ }^{13}$ G. Lundestad, op. cit., pp. 86-91.

${ }^{14}$ K. Deutsch et al., Political Community and the North Atlantic Area: International Organization in the Light of Historical Experience, Princeton University Press, Princeton 1957.

15 B. Long, No Easy Occupation. French Control of the German Saar, 1944-1957, Camden House, Rochester/New York 2015, p. 192.

16 K. Ruane, Agonizing Reappraisals: Anthony Eden, John Fuster Dulles and the Crisis of European defence, 1953-1954, "Diplomacy \& Statecraft", Vol. 13, No. 4/2002, p. 151; K.H. Jarausch, Out of the Ashes. A New History of Europe in the Twentieth Century, Princeton University Press, Princeton and Oxford 2015, p. 512. 


\section{From the European Defence Community to an 'Empire by Invitation'?}

The European Defence Community (EDC) Treaty was signed on $27^{\text {th }}$ May 1952. It laid down procedures for US and British cooperation with the EDC following ratification of the Treaty by all signatories. It was also decided that the military occupation of Germany would then come to an end. ${ }^{17}$ The West German government ratified the Treaty in March 1953. Political and military integration should, as it was written, be limited as much as possible, and Great Britain and the United States should be involved as much as possible in Western European defence structures. ${ }^{18}$ The 1948 Brussels Treaty was expanded to become the basis for the Western European Union (WEU), of which West Germany became a member. The newly established West German army - the Bundeswehr - would only be 500,000 men strong, and the FRG joined NATO as a sovereign state in 1955. This defence constellation would last until the end of the Cold War in Europe, despite occasional renewed calls for a separate European foreign and security policy, as in the 1961 Fouchet Plan. The involvement of the US thus became an important factor in the early stages of European integration, tempting scholars to interpret the transatlantic community as an "Empire by Invitation": In his seminal 1986 article, Geir Lundestad claimed that the involvement of the Americans in Western Europe was not forced upon the Europeans, but actually came about by invitation, as the Europeans lobbied the US to become more involved in European affairs. ${ }^{19}$ Especially to the smaller Western European countries, as well as to Great Britain, it was imperative that the US had a strong US military presence on the continent. The Belgian Prime and Foreign Minister Paul-Henri Spaak even held that "any defence arrangements which did not include the United States were without practical value" - as did the Dutch government. ${ }^{20}$

However, this stronger American involvement in European defence affairs created a paradox for the development of a separate European security identity that would endure until the end of the Cold War and

17 T. Judt, op. cit., p. 244.

18 D. Hellema, Neutraliteit \& Vrijhandel. De geschiedenis van de Nederlandse buitenlandse betrekkingen, Het Spectrum, Utrecht 2001, p. 168; M. Lak, Tot elkaar veroordeeld. De Nederlands-Duitse economische en politieke betrekkingen tussen 1945-1957, Verloren, Hilversum 2015, p. 252.

19 G. Lundestad, Empire by Invitation? The United States and Western Europe, 19451952, "Journal of Peace Research", Vol. 23, No. 3/1986, p. 268; G. Lundestad, The Rise $\&$ Decline of the American "Empire". Power and its Limits in Comparative Perspective, Oxford University Press, Oxford 2012, p. 176.

20 G. Lundestad, Empire by Invitation?..., op. cit., p. 269. 
beyond. Lundestad notes that a path dependency had set in: "Once the Americans had increased their commitment to NATO, this provided little inducement for the Europeans to do their part". ${ }^{21}$ An "empire", however, lacks this consensual element which had been present in Europe's defence arrangements for much of the Cold War. ${ }^{22}$ The US's involvement in European defence was therefore never an "empire by invitation", as European consent had complemented what otherwise might have been considered a US imperial logic - at least in the realist (and Marxist) schools of thought in IR scholarship, which bases definitions of empire on coercive force and economic exploitation. ${ }^{23}$

While US-European relations entailed traits of 'hierarchic' imperial programmes, to use David Lake's formulation, ${ }^{24}$ the historical evidence outlined above suggests a level of European consent to the projection of American power in Europe. ${ }^{25}$ Arguing that the US involvement in Europe did not fit an "imperial" framework conceptually, John Lewis Gaddis therefore wrote of "expansion by invitation" to qualify Lundestad's original thesis. ${ }^{26}$ Misgivings and ruptures, however, have let calls for more "strategic autonomy" flare up periodically. The Vietnam war in the late 1960s, the Nixon presidency, as well as the victory of Ronald Reagan deepened the divide between Europe and America. As external framework conditions changed in the 1990s, however, calls for "strategic autonomy" grew louder. The next section therefore discusses how this invitational aspect has shifted as the cognitive Cold War layer was lifted in 1991.

\section{A New Momentum for European Defence Autonomy?}

After the end of the Cold War, the idea of European defence structures separate from NATO was revived. Reminiscent of policy debates during the 1950s, disagreements arose between EU member states over the balance

${ }^{21}$ Ibidem, p. 272.

22 O. Worth, Beyond world order and transnational classes. The (re)application of Gramsci in global politics, in: Gramsci and global politics: hegemony and resistance, eds. M. McNally, J. Schwarzmantel, Routledge, London and New York 2009; O. Worth, Recasting Gramsci in international politics, "Review of International Studies", Vol. 37, No. 1/2011, pp. 373-392.

23 A. Baker, American empire - a dangerous distortion?, "Review of International Studies", Vol. 26/2010, p. 2.

${ }^{24}$ D. Lake, Entangling Relations: American Foreign Policy in its Century, Princeton University Press, Princeton 1999, p. 41.

25 R.J. Granieri, Allies and Other Strangers: European Integration and the American “Empire by Invitation”, "Foreign Policy Research Institute”, Fall 2006, pp. 691-707.

26 J.L. Gaddis, The Long Peace: Inquiries into the History of the Cold War, Oxford University Press, Oxford 1987, p. 59. 
between Atlantic solidarity and further European integration. ${ }^{27}$ However, the EU's ideas of defence autonomy in the 1990s were quickly rejected by the Americans. US Secretary of State Madeleine Albright warned of the "Three D's"28: no duplication, no discrimination (against non-EU NATO allies, e.g. Turkey) and no decoupling (of ESDP from NATO). Former US Ambassador to NATO Nicholas Burns even called ESDP a "wasteful, unnecessary and disruptive competitor". ${ }^{29}$ As European consent began to shift and the invitational aspect was relaxed, US administrations reacted by reclaiming imperial control in order to keep Europe within NATO to avoid any strategic duplication. The 'European Security and Defence Identity' was seen as an unnecessary competitor to NATO, even though the European Security and Defence Identity (ESDI) within the context of NATO had been an effort to strengthen the European pillar of the Atlantic Alliance and was therefore explicitly not intended to make the EU independent militarily.

The introduction of a European Security and Defence Policy (ESDP) in Cologne in 1999, together with a capabilities catalogue in order to be able to fully implement the Petersberg Tasks which had already existed within the framework of the WEU, then raised the possibility that a further strengthening of the ESDP could undermine NATO. ${ }^{30}$ In December 2002, the Heads of Government thus agreed upon the arrangements of the Berlin Plus Agreement. ${ }^{31}$ This declaration was meant to institutionalise a mutually-reinforcing strategic partnership in the realm of military capabilities and crisis management activities, built on transparent consultation and cooperation structures. At the same time, this development implicitly installed NATO as primus inter pares. "Berlinplus" was to be the first option for future EU missions. In 2003, the EU led its first ever military operation in the former Yugoslav Republic of

27 S. Keukeleire, J. MacNaughtan, The Foreign Policy of the European Union, Palgrave, Basingstoke 2008, p. 10.

28 A. Toje, America, the EU and Strategic Culture. Renegotiating the Transatlantic Bargain, Routledge, London and New York 2008, p. 105.

29 A. Ambos, NATO-EU Relations, in: European Foreign Policy - From Rhetoric to Reality?, eds. D. Mahncke, A. Ambos, C. Reynolds, College of Europe Studies, 2004, p. 187.

${ }_{30}$ W. Rees, The US-EU Security Relationship, Palgrave Macmillan, Basingstoke 2011, p. 65 .

31 Five main principles were set within the EU-NATO relationship: 1) effective and mutual consultation; 2) equality and due regard for the decision-making autonomy of the EU and NATO; 3 ) respect for the interests of the EU and NATO members states; 4) respect for the principles of the Charter of the United Nations; 5) coherent, transparent and mutually reinforcing development of the military capability requirements common to the two organizations (NATO 2004). 
Macedonia as a take-over of NATO's mission Allied Harmony. While US administrations may have wanted a veto over European defence developments, the natural corollary in Europe again became a reliance on US predominance in security affairs. "American leadership has generated a degree of demotivation on the part of Europeans, which US commentators have castigated as 'free-riding", Jolyon Howorth notes. ${ }^{32}$ Genuine European defence autonomy ambitions again subsided as elements of an 'Empire by Invitation' were perpetuated to the extent that the spirit of "Berlin-plus" sought to de-conflict tensions over a renewed "strategic autonomy" debate in Europe in the 1990s. This was despite the formal introduction of a European Security and Defence Policy at Maastricht in 1992, renamed the Common Security and Defence Policy (CSDP) with the 2009 Lisbon Treaty. Kempin \& Mawdsley argue that the CSDP lacks a sense of strategy and purpose and represents a "continuation of US hegemony in defence and security policy"- thereby aptly capturing the consensual logic underpinning this arrangement. ${ }^{33}$ Adopting a similar argumentation, Serfati argued that the EU as a regional hegemon has largely perpetuated US Order conceptions. ${ }^{34}$ The election of Donald Trump as US president in November 2016 constituted a disruptive element at the level of rhetoric in this transatlantic hegemonic arrangement that had been created with US involvement in European defence affairs. The remainder of the article seeks to assess whether the current rift in transatlantic relations represents a qualitatively different challenge in light of previous disagreements over defence policies, and how in-built constraints in Europe's defence autonomy as outlined above complicate the attainment of European "strategic autonomy".

\section{EU Defence Structures and US Reactions to Them}

The shock waves that the US presidential election has sent throughout the European foreign and security policy community cannot be exaggerated. ${ }^{35}$ Trump has castigated the Europeans for not paying for

32 J. Howorth, EU-NATO cooperation: the key to Europe's security future, "European Security", Vol. 26, No. 3/2017, p. 456.

33 R. Kempin, J. Mawdsley, The Common Security and defence Policy as an act of American hegemony, "European Security", Vol. 22, No. 1/2013, p. 56.

34 S. Serfati, Impérialisme et militarisme: actualité du XXIe siècle, Éditions Page Deux, Lausanne 2004.

${ }^{35}$ A. Meier, U. Scheffer, Militärische Zusammenarbeit in der EU: ein Meilenstein dank Donald Trump, „Euractiv“, 14 November 2017, https://www.euractiv.de/section/ eu-aussenpolitik/news/militaerische-zusammenarbeit-in-der-eu-ein-meilenstein-dank-donald-trump/ (access 24.09.2019). 
their security protection, a reproach he repeated during his address at the 2017 NATO summit in Brussels. ${ }^{36}$ For the first time in seven decades, a US president openly started criticising NATO's utility to provide unconditional security for allies, and the purpose of the European project in itself. ${ }^{37}$ The consensual aspect of the EU-US defence relationship began to shift again, but this time on the forcible initiative of the US. The debate about consolidating EU defence structures triggered by the 'Trump factor' is ironic: European attempts to develop defence autonomy in the 1990s had been criticized by the Americans as a wasteful duplication of NATO, while it now was American criticism of these very NATO mechanisms that propelled Europeans to act. There is considerable uncertainty as to whether Trump's unprecedented rhetoric is a symptom of a long-term tectonic shift or a temporary phenomenon. As Ivan Krastev has put it, Trump does not believe in allies, but only distinguishes between "fans and enemies". ${ }^{38}$

The EU, one possible conclusion goes, should therefore stand up for a transformation of multilateralism against the background of an imperilled liberal international order. ${ }^{39}$ Other voices err on the side of caution. ${ }^{40}$ The transatlantic rift during the Nixon administration in the 1970s or the sense of renewed crisis when Ronald Reagan assumed the presidency is a reminder that cyclical disruptions are built into the EUUS relationship, ${ }^{41}$ and that Trump is not the first US president to criticise European security policies. In 2003, the European Security Strategy was partly drafted as a European response to the US-led war in Iraq. ${ }^{42}$

36 D. Boffey, J. Rankin, Trump rebukes Nato leaders for not paying defence bills, "The Guardian", 25 May 2017, https://www.theguardian.com/world/2017/may/25/trumprebukes-nato-leaders-for-not-paying-defence-bills (access 21.11.2017).

37 B. Woodward, Fear. Trump in the White House, Simon \& Schuster, London 2018.

38 I. Krastev, Sorry, NATO. Trump Doesn't Believe in Allies, "The New York Times", 11 July 2018, https://www.nytimes.com/2018/07/11/opinion/trump-nato-summit-allies. html (access 24.11.2017).

39 N. Tocci, The Demise of the International Liberal Order and the Future of the European Project, Istituto Affari Internazionali, November 2018, http://www.iai.it/en/ pubblicazioni/demise-international-liberal-order-and-future-european-project (access 24.09.2019).

${ }^{40}$ T. Kleine-Brockhoff, Ohne, aber nicht gegen Washington, "Internationale Politik”, November/December 2018, pp. 38-47.

${ }^{41}$ W. Rees, op. cit., pp. 3-4.

42 M. Mälksoo, From the ESS to the EU Global Strategy: external policy, internal purpose, "Contemporary Security Policy", Vol. 37, No. 3/2016, p. 378. For analyses of the 2003 ESS, see S. Duke, The European Security Strategy in a Comparative Framework: Does it Make for Secure Alliances in a Better World?, "European Foreign Affairs Review", Vol. 9/2004, pp. 459-481; The EU and the European Security Strategy. Forging a global 
Debates surrounding Europe as a point of resistance to US hegemony at the time were reminiscent of debates during the 1990s about European emancipation from US unipolarity after the end of the Cold War. "Martian" US policies were juxtaposed with "Venusian" EU approaches, ${ }^{43}$ and the US further drove a wedge into the EU's divergent positions with the use of Donald Rumsfeld's discourse on 'Old' vs. 'New' Europe. Analysts were busy understanding reasons and prospects for the new transatlantic rift. ${ }^{44}$ Some argued that the Bush administration was bent on establishing an empire by military might. ${ }^{45}$

Likewise, Trump's rhetoric generates divided views, as policy signals emanating from the Trump administration remain ambiguous. Trump's initial harsh rhetoric on NATO has not been followed up by shifts in the US position towards its military allies. ${ }^{46}$ The American "deep engagement" in European affairs, ${ }^{47}$ as some analysts have argued, is too resilient a structure to allow for the agency of the presidency to destroy it from within. ${ }^{48}$ It should also not be forgotten that the US criticism predates the Trump administration, pointing to a level of foreign policy continuity as far as US perceptions of European security is concerned. Disagreements under Obama focused on Europe being not autonomous enough.

US President Obama's mantra of "leading from behind" during the 2011 Libyan crisis was conceived as an 'anti-free rider campaign' in military and defence matters, as Obama himself put it in an interview with The Atlantic. ${ }^{49}$ Here, the idea of 'emancipation' from the US looms large in the EU's attempts to re-define Europe's place in the world. But

Europe, eds. S. Biscop, J.J. Andersson, Routledge, London and New York 2008; G. Quille, The European Security Strategy: a framework for EU security interests?, "International Peacekeeping", Vol. 11, No. 3/2007, pp. 422-438.

${ }^{43}$ R. Kagan, Of Paradise and Power: America and Europe in the New World Order, Alfred Knopf, New York 2003.

${ }^{44}$ G. Lundestad, The United States..., op. cit.; N. Kotzias, P. Liacouras, EU-US Relations: Repairing the Transatlantic Rift, Palgrave Macmillan, New York 2006.

45 R.A. Falk, The Declining World Order. America's Imperial Geopolitics, Routledge, London and New York 2004; I.H. Daalder, J.M. Lindsay, America Unbound: The Bush Revolution in Foreign Policy, Wiley, New York 2003.

${ }^{46}$ B. Woodward, op. cit.

${ }^{47}$ T. Wright, A post-American Europe and the future of U.S. strategy, "Brookings Report", December 2017, https://www.brookings.edu/research/a-post-american-europeand-the-future-of-u-s-strategy/ (access 24.11.2017).

48 D. Stokes, Trump, American hegemony and the future of the liberal international order, "International Affairs", Vol. 94, No. 1/2018, p. 134.

${ }^{49}$ G. Goldberg, The Obama Doctrine, "The Atlantic", April Issue 2016, http://www. theatlantic.com/magazine/archive/2016/04/the-obama-doctrine/471525/ (access 24.11.2017). 
beyond all talk of enhanced European military cooperation, the EU has lacked a strategic debate about security. The development of its defence structures has been reactionary, and has tended to follow Americandominated structures, as analysed above. CSDP has been more "capacitydriven than strategy-led". ${ }^{50}$

Kempin and Mawdsley point out the central role that "US military hegemony" plays within NATO and that "the US sets the NATO agenda". ${ }^{51}$ Building on Webber, ${ }^{52}$ they cite US pre-dominance when it comes to major policy changes, military doctrines and technology within NATO. Advancing 'strategic autonomy' would therefore either require a decoupling from NATO and the creation of independent European defence structures (through CSDP), or the strengthening of the European pillar within NATO. The latter is generally considered the most realistic option amongst expert and policy communities. ${ }^{53}$ Reacting to Trump's persistent criticism of European free-riding as well as his scorn for multilateral commitments, the German government has been advancing an 'Alliance for multilateralism'. German foreign minister Heiko Maas outlines the link of such an 'alliance' to the discourse about a 'new strategic reality' as follows:

"When Europe is branded in the same breath as an adversary along with Russia and China, when the NATO alliance is almost casually called into question, then this isn't just a question of rhetoric. This gives rise to a new strategic reality that we must come to grips with. [...] By strengthening the European pillar of the transatlantic alliance, we are creating the conditions for ensuring that Americans and Europeans can rely on each other also in the future". ${ }^{54}$

In addition, the level of logistical entanglement serves to illustrate why a separation of EU defence structures from NATO structures would be a near-impossibility: NATO Prague Capabilities Commitments resemble the Helsinki Headline Goal, NATO's 'smart defence' resembles the aim of "pooling and sharing" (Ghent Framework). Autonomy from the US

$50 \mathrm{~J}$-Y. Haine, The failure of a European strategic culture - EUFOR CHAD: the Last Of its kind?, "Contemporary Security Policy", Vol. 32, No. 3/2011, p. 585.

${ }^{51}$ R. Kempin, J. Mawdsley, op. cit., p. 59.

${ }_{52}$ M. Webber, NATO: the United States, transformation and the war in Afghanistan, "British Journal of Politics and International Relations", Vol. 11, No. 1/2009, pp. 46-63.

53 J. Howorth, The Lisbon Treaty, CSDP and the EU as a Security Actor, in: The EU'S Foreign Policy. What Kind of Power and Diplomatic Action?, eds. M. Telò, F. Ponjaert, Ashgate, Farnham 2013, p. 75.

${ }^{54}$ H. Maas, Speech by Foreign Minister Heiko Maas at the opening of the $16^{\text {th }}$ Ambassadors Conference at the Federal Foreign Office, 2018, https:/www.auswaertiges-amt.de/ en/newsroom/news/maas-freeland-ambassadors-conference/2130332 (access 24.09.2019), emphasis added. 
is thus being made all the more difficult by an institutional copying that duplicates capacities in function and purpose. ${ }^{55}$ Ronja Kempin and Barbara Kunz thus argue that "[i]t thus makes little sense for U.S.-skeptic Europeanists to pit themselves against Atlanticists as if we were back in de Gaulle's 1960s or the post-Cold War 1990s". ${ }^{56}$

The notification of November 2017 to formally launch PESCO recognizes as much. The Council states: "Enhanced defence capabilities of EU Member States will also benefit NATO. They will strengthen the European pillar within the Alliance and respond to repeated demands for stronger transatlantic burden sharing" (p. 1), and writes of the need to ensure "interoperability with NATO" (p. 5). The mechanism of Permanent Structured Cooperation, introduced by the Lisbon Treaty but never implemented, was launched on 23 June 2017. The ambition behind the realization of PESCO is to allow EU member states to work more closely together in the area of security and defence issues by providing "an ambitious, binding and inclusive European legal framework for investments in the security and defence of the EU's territory and its citizens", as the notification reads. ${ }^{57}$ On a broader conceptual level, the Commission has also launched its own White Paper on the future of Europe..$^{58}$ Member states willing to cooperate more on defence matters would be able to do so under the third scenario put forward in the Commission White Paper ("those who want more do more"). As the Commission puts this vision of a multi-speed Europe in security affairs: "This includes a strong common research and industrial base, joint procurement, more integrated capabilities and enhanced military readiness for joint missions abroad". ${ }^{59}$ Interestingly, scenario 4 ("doing less more efficiently") talks of a "European defence Union" that would be able to speak with one voice on all foreign policy issues. ${ }^{60}$

${ }_{55}$ R. Kempin, J. Mawdsley, op. cit., p. 61.

${ }^{56}$ R. Kempin, B. Kunz, Washington Should Help Europe Achieve 'Strategic Autonomy, 'Not Fight It. War on the Rocks, Commentary, 12 April 2018, https://warontherocks. com/2018/04/washington-should-help-europe-achieve-strategic-autonomy-not-fight-it/ (access 24.11.2017).

57 Notification on Permanent Structured Cooperation (PESCO) to the Council and to the High Representative of the Union for Foreign Affairs and Security Policy, EU Council (2017), 13 November 2017, http://www.consilium.europa.eu/media/31511/171113-pesconotification.pdf (access 24.11.2017).

58 White Paper on the Future of Europe. Reflections and scenarios for the EU27 by 2025, EU Commission, March 2017, https://ec.europa.eu/commission/sites/beta-political/ files/white_paper_on_the_future_of_europe_en.pdf (access 24.11.2017).

59 Ibidem.

${ }^{60}$ Ibidem, p. 23. 
The EU Council's decision to upgrade the Military Planning and Conduct Capability (MPCC) to 60 permanent staff in order to run Battlegroup-size executive military CSDP missions by the end of 2020 is an important step in this direction of 'strategic autonomy' (EEAS, 2018). ${ }^{61}$ The NATO Defence Planning Process (NDPP) would also need to define what capabilities are required of European contributors, if Europeans want to contribute to Article 5 operations, non-Article 5 operations without the US and other non-EU Allies (Norway, Turkey, Canada), and to be in a position to conduct autonomous expeditionary operations. But to do that, the EU will have to commence a genuine strategic debate that would serve as a framework to channel its resurfaced defence ambitions in order to credibly embed CSDP within a wider understanding of what 'strategic autonomy' should entail across multiple policy domains. The 2016 EU Global Strategy takes up the term of 'strategic autonomy' and develops European policy responses to the multiple challenges that the EU is confronted with (EU Council 2016). ${ }^{62}$ The EU "will take responsibility foremost in Europe and its surrounding regions", as the EUGS states.

The "strategic partners" in far-away places like Brazil, China, or India, by contrast, no longer play a discernible role. After its publication, additional policy papers were released that were indicative of an accelerated move towards greater defence cooperation, such as the European Security Compact (a joint Franco-German paper, Ayrault and Steinmeier, 2016), the Bratislava Road Map issued by the European Council on 16th September 2016, the EP's vote on the European defence Union on 30th November 2016, the Commission's European defence Action Plan, and its 2017 Reflection paper on the future of European defence. Even the Commission, "traditionally reluctant to name the ' $D$ ' word", ${ }^{63}$ was supportive, and has put forward the idea of a European Defence Fund (EDF) in June 2017. With this fund, €5.5 billion could be spent per year 'to boost Europe's defence capabilities' in support of the implementation of the EU Global Strategy, as the Commission

61 European External Action Service (EEAS), 'The Military Planning and Conduct Capability (MPCC)', November 2018, https://cdn4-eeas.fpfis.tech.ec.europa.eu/cdn/farfuture/aGKF41zrLDLuNeg8csm24scxmjEwj4JBvrRbaLeaY4M/mtime:1542656575/ sites/eeas/files/mpcc_factsheet_november_2018.pdf?fbclid=IwAR0aedfsdSDmzli6o7Mu zWGeU11iuhunQvȲ̄WeYzmcHBvDC53psf30XOWmw (access 24.09.2019).

${ }^{62}$ EU Global Strategy: Implementation plan on security and defence, Infographic, EU Council, 2016.

${ }^{63}$ N. Tocci, The making of the EU Global Strategy, "Contemporary Security Policy", Vol. 37, No. 3/2016, p. 468. 
announcement reads ${ }^{64}$ The momentum for new defence policies, however, is complicated by corporate and political factors. Defence companies follow their own industrial logic, no matter how hard political leadership tries to push things in a certain direction. ${ }^{65}$ Mutual reservations within the Eurofighter consortium illustrate the difficulty of creating truly European (i.e. transnational) defence contractors. ${ }^{66}$

Moreover, while the rhetoric of the US president has generated a renewed drive towards advancing "strategic autonomy", the latter is unlikely to move beyond its buzzword use for as long as the EU remains an institutional vessel for its member states to agree to disagree on what to use it for in security and defence matters. For example, it irritated the Baltic states and frustrated the French that a truly operational PESCO beyond the PR merits of its declaration - was of secondary importance to the Germans, ${ }^{67}$ and Eastern European member states tend to place greater confidence in bilateral US security guarantees than others. A realistic reformulation of a European security identity is therefore likely to be based on enhanced cooperation between groups of countries that want to do more (as the 2017 Commission White Paper puts it), not on an EUwide consolidated effort. The introduction of Qualified Majority Voting (QMV) in the Foreign Affairs Council would be a further step in that direction, but is unlikely to materialise in a Union of 27 , as attempts to circumvent consensus requirements in foreign policy questions continue to be perceived as sovereignty losses. This makes swift changes to transatlantic defence arrangements less likely.

\section{Conclusions}

Tracing the evolution of EU security and defence policies, this article has illustrated how European defence developments have often been reactive to American positions and perceptions. European security was conditional on the transatlantic element, but also complicated by the

${ }^{64}$ A European Defence Fund: 65.5 billion per year to boost Europe's defence capabilities, EU Commission, Press Release, 7 June 2017, http://europa.eu/rapid/press-release IP-17-1508 en.htm (access 24.09.2019).

${ }_{65}$ J. Howorth, EU-NATO cooperation ..., op. cit., p. 456.

${ }^{66}$ Exploring the 'Bullshit Castle'. Airbus Corruption Scandal May Lead Straight to the Top, "SPIEGEL online", 9 October 2017, http://www.spiegel.de/international/business/airbus-corruption-scandal-threatens-ceo-tom-enders-a-1171533-2.html (access 24.11.2017).

${ }^{67}$ J. Puglierin, Rolle rückwärts, "Internationale Politik", September/October, No. 5/2018, pp. 8-13; M. Dahl, Germany and the Common Security and defence Policy, "Studia Europejskie - Studies in European Affairs", Issue 4/2018, pp. 85-96. 
nature of intergovernmentalism in security affairs, national divergences in security cultures, and an absence of an EU-wide consensus as to what level of ambition in this domain is desirable. The two key issues of West German rearmament and the role of the US in nascent European defence ambitions dominated the discussion in the late 1940s and early 1950s and have served to forge a transatlantic community as an "Empire by Invitation": as Europe invited the US in, it stymied security divergences between European member states. The failure of the Pleven plan and the EDC were indicative of the difficulty of bridging the divide between Atlanticists and those member states in favour of more European security and defence autonomy.

The second part of the paper showed how similar dividing lines quickly resurfaced after the end of the Cold War, when the debate surrounding the European Security and Defence Identity alluded to renewed ambitions to develop a distinct European voice in security affairs. We have argued that European consent to considerable US involvement in defence affairs has hampered the development of such autonomy as much as intra-European divergences on this policy domain have. The EU-US relationship has undergone cyclical disruptions during, but more so after the end of the Cold War, yet the election of a new US president in 2016 has called its underpinning logic into question more forcefully than ever at a level of official policy discourse.

As an external trigger factor, Donald Trump's election and his scathing critique of NATO and Europe's budgetary contributions to its defence expenditures has therefore elevated the EU's CSDP ambitions to a new level. With a rather astonishing pace, strategy papers have been published, the Commission put forward the idea of a European Defence Fund (EDF) in June 2017, and "Permanent Structured Cooperation" (PESCO), a mechanism for closer defence cooperation already foreseen in the Lisbon Treaty, was finally launched and activated in November 2017 (EU Council 2017) - even though the piecemeal streamlining of the operational, industrial, and political components of "strategic autonomy" leaves much to be desired. ${ }^{6}$

Finally, the state of CSDP and the public debate surrounding it needs to be put into a broader global context beyond transatlantic relations: The necessity for an overhaul of Europe's global strategy was underlined against the background of the 2015 migration crisis, terrorist attacks in Europe and the inadequacy of European intelligence-sharing they exposed. A genuine strategic voice is not only needed in light of the

${ }^{68}$ R. Kempin, B. Kunz, op. cit. 
often-discussed foreign policy re-orientations of actors like Russia and China, but also in light of the EU's own passive response to crises in its own neighbourhood. It was this general state of alert that is reflected in a German military study entitled "Strategic Perspective 2040", which outlines different scenarios for the development of the international order. In the worst-case scenario, the study holds, "EU enlargement has been largely abandoned, other states have left the community, Europe has lost its global competitiveness". ${ }^{69}$ The launch of PESCO in 2017 will not be the panacea for Europe's search for a solution to the twin challenges of uncertainties in transatlantic relations and crises in the European neighbourhood and the Eurasian theatre, but can only be one element amongst many. 'Strategic autonomy' goes beyond CSDP. Yet, the brief historical overview of US-EU interaction on questions of institutional innovation presented in this paper has demonstrated that the transatlantic defence cooperation has been a crucial factor in enabling a margin of permissiveness for any European 'strategic autonomy' to develop.

\section{References}

A European Defence Fund: $€ 5.5$ billion per year to boost Europe's defence capabilities, Press Release, 7 June 2017, http://europa.eu/rapid/pressrelease_IP-17-1508_en.htm (access 24.09.2019).

Ambos A., NATO-EU Relations, in: European Foreign Policy - From Rhetoric to Reality?, eds. D. Mahncke, A. Ambos, C. Reynolds, College of Europe Studies, 2004.

Baker A., American empire - a dangerous distortion?, "Review of International Studies", Vol. 26/2010, pp. 1-11, DOI: https://doi.org/10.1017/ S0260210510000331.

Boffey D., Rankin J., Trump rebukes Nato leaders for not paying defense bills, "The Guardian", 25 May 2017, https://www.theguardian.com/ world/2017/may/25/trump-rebukes-nato-leaders-for-not-payingdefense-bills (access 21.11.2017).

Brunn G., Die Europaïsche Einigung von 1945 bis heute, Bundeszentrale für politische Bildung, Bonn 2006.

Buyck C., German military study: EU collapse conceivable worst case, "Politico", 11 April 2017, "Politico", 11 April 2017, https://www.politico.eu/article/ german-military-study-eu-collapse-is-conceivable/ (access 24.09.2019).

${ }^{69}$ C. Buyck, German military study: EU collapse conceivable worst case, "Politico", 11 April 2017, https:/www.politico.eu/article/german-military-study-eu-collapse-is-conceivable/ (access 24.09.2019). 
Daalder I.H., Lindsay J.M., America Unbound: The Bush Revolution in Foreig Policy, Wiley, New York 2003.

Deutsch K. et al., Political Community and the North Atlantic Area: International Organization in the Light of Historical Experience, Princeton University Press, Princeton 1957.

Duke S., The European Security Strategy in a Comparative Framework: Does it Make for Secure Alliances in a Better World?, "European Foreign Affairs Review", Vol. 9/2004, pp. 459-481.

EU Global Strategy: Implementation plan on security and defence, Infographic, https://www.consilium.europa.eu/en/infographics/eu-global-strategy/ (access 24.11.2017).

Exploring the "Bullshit Castle". Airbus Corruption Scandal May Lea Straight to the Top, SPIEGEL online, 9 October 2017, http://www.spiegel.de/ international/business/airbus-corruption-scandal-threatens-ceo-tomenders-a-1171533-2.html (access 24.11.2017).

Falk R.A., The Declining World Order. America's Imperial Geopolitics, Routledge, London/New York 2004.

Gaddis J.L, The Long Peace: Inquiries into the History of the Cold War, Oxford University Press, Oxford 1987.

Goldberg G., The Obama Doctrine, The Atlantic, April Issue 2016, http://www.theatlantic.com/magazine/archive/2016/04/the-obamadoctrine/471525/ (access 24.11.2017).

Granieri R.J., Allies and Other Strangers: European Integration and the American "Empire by Invitation", "Foreign Policy Research Institute", Fall 2006, pp. 691-707, DOI: https://doi.org/10.1016/j.orbis.2006.07.009.

Haine J.Y., The failure of a European strategic culture - EUFOR CHAD: the Last Of its kind?, "Contemporary Security Policy", Vol. 32, No. 3/2011, pp. 582-603, DOI: https://doi.org/10.1080/13523260.2011.623060.

Hellema D., Neutraliteit $\mathcal{E}$ Vrijhandel. De geschiedenis van de Nederlandse buitenlandse betrekkingen, Het Spectrum, Utrecht 2001.

Hoffmann S., Discord in Community: The North Atlantic Area as a Partial International System, "International Organization", Vol. 17, No. 3/1963, pp. 521-549, DOI: https://doi.org/10.1017/S0020818300034536.

Howorth J., Keeler J.T.S., Defending Europe. The EU, NATO and the Quest for European Autonomy, Palgrave Macmillan, Basingstoke 2003, DOI: https://doi.org/10.1057/9781403981363_1.

Howorth J., EU-NATO cooperation: the key to Europe's security future, "European Security", Vol. 26, No. 3/2017, pp. 454-459, DOI: https:// doi.org/10.1080/09662839.2017.1352584.

Howorth J., The Lisbon Treaty, CSDP and the EU as a Security Actor, in: The EU's Foreign Policy. What Kind of Power and Diplomatic Action?, eds. M. Telò, F. Ponjaert, Ashgate, Farnham 2013. 
Jarausch K.H., Out of the Ashes. A New History of Europe in the Twentieth Century, Princeton University Press, Princeton and Oxford 2015, DOI: https://doi.org/10.1515/9781400865598.

Judt T., Postwar. A History of Europe Since 1945, Pimlico, London 2015.

Kagan R., Of Paradise and Power: America and Europe in the New World Order, Alfred Knopf, New York 2003.

Kempin R., Kunz B., Washington Should Help Europe Achieve Strategic Autonomy, Not Fight It, War on the Rocks, Commentary, 12 April 2018, https://warontherocks.com/2018/04/washington-should-help-europeachieve-strategic-autonomy-not-fight-it/ (access 24.11.2017).

Kempin R., Mawdsley J., The Common Security and Defense Policy as an act of American hegemony, "European Security", Vol. 22, No. 1/2013, pp. 55-73, DOI: https://doi.org/10.1080/09662839.2012.726221.

Keukeleire S., MacNaughtan J., The Foreign Policy of the European Union, Palgrave, Basingstoke 2018.

Kleine-Brockhoff T., Ohne, aber nicht gegen Washington, "Internationale Politik" November/December 2018, pp. 38-47.

Kotzias N., Liacouras P., EU-US Relations: Repairing the Transatlantic Rift, Palgrave Macmillan, New York 2006, DOI: https://doi. org/10.1057/9780230503670.

Krastev I., Sorry, NATO. Trump Doesn't Believe in Allies, The New York Times, 11 July 2018, https://www.nytimes.com/2018/07/11/opinion/ trump-nato-summit-allies.html (access 24.11.2017).

Lak M., The Early Years of European Integration - German and Dutch Reactions to the Schuman Plan, in: Governance and Security Issues of the European Union. Challenges Ahead, eds. J. de Zwaan, M. Lak, A. Makinwa, P. Willems, T.M.C. Asser Press, The Hague 2016, pp. 11-32, DOI: https://doi.org/10.1007/978-94-6265-144-9_2.

Lak M., Tot elkaar veroordeeld. De Nederlands-Duitse economische en politieke betrekkingen tussen 1945-1957, Verloren, Hilversum 2015.

Lake D., Entangling Relations: American Foreign Policy in its Century, Princeton University Press, Princeton 1999.

Lippert B., von Ondarza N., Perthes V., European Strategic Autonomy. Actors, Issues, Conflicts of Interests, "SWP Research Paper”, No. 4, March 2019.

Long B., No Easy Occupation. French Control of the German Saar, 19441957, Camden House, Rochester/New York 2015.

Lundestad G., Empire by Invitation? The United States and Western Europe, 1945-1952, "Journal of Peace Research", Vol. 23, No. 3/1986, pp. $263-$ 277, DOI: https://doi.org/10.1177/002234338602300305.

Lundestad G., The Rise E Decline of the American "Empire". Power and its Limits in Comparative Perspective, Oxford University Press, Oxford 2012. 
Lundestad G., The United States and Western Europe since 1945: from 'empire' by invitation to transatlantic drift, Oxford University Press, Oxford, DOI: https://doi.org/10.1093/0199266689.001.0001.

Maas H., Speech by Foreign Minister Heiko Maas at the opening of the $16^{\text {th }}$ Ambassadors Conference at the Federal Foreign Office, https://www. auswaertiges-amt.de/en/newsroom/news/maas-freeland-ambassadorsconference/2130332 (access 24.09.2019).

Macron E., Speech at Sorbonne University, 26 September 2017, http:// international.blogs.ouest-france.fr/archive/2017/09/29/macronsorbonne-verbatim-europe-18583.html (access 10.07.2019).

Mälksoo M., From the ESS to the EU Global Strategy: external policy, internal purpose, "Contemporary Security Policy", Vol. 37, No. 3/2016, pp. 374388, DOI: https://doi.org/10.1080/13523260.2016.1238245.

Meier A., Scheffer U., Militärische Zusammenarbeit in der EU: ein Meilenstein dank Donald Trump, "Euractiv", 14 November 2017, https://www.euractiv.de/section/eu-aussenpolitik/news/militaerischezusammenarbeit-in-der-eu-ein-meilenstein-dank-donald-trump/ (access 24.09.2019).

Merkel A., Rede von Bundeskanzlerin Merkel vor dem Europäischen Parlament am 13. November 2018 in Straßburg. 13 November, https://www. bundeskanzlerin.de/bkin-de/aktuelles/rede-von-bundeskanzlerinmerkel-vor-dem-europaeischen-parlament-am-13-november-2018-instrassburg-1549538 (access 24.08.2019).

Notification on Permanent Structured Cooperation (PESCO) to the Council and to the High Representative of the Union for Foreign Affairs and Security Policy, 13 November 2017, http://www.consilium.europa.eu/ media/31511/171113-pesco-notification.pdf (access 24.11.2017).

Puglierin J., Rolle rückwärts, "Internationale Politik", September/October, No. 5/2018, pp. 8-13.

Quille G., The European Security Strategy: a framework for EU security interests?, "International Peacekeeping", Vol. 11, No. 3/2007, pp. 422438, DOI: https://doi.org/10.1080/1353331042000249028.

Rees W., The US-EU Security Relationship, Palgrave Macmillan, Basingstoke 2011, DOI: https://doi.org/10.1007/978-1-137-28556-0.

Ruane K., Agonizing Reappraisals: Anthony Eden, Fohn Fuster Dulles and the Crisis of European Defense, 1953-1954, "Diplomacy \& Statecraft", Vol. 13, No. 4/2002, pp. 151-185, DOI: https://doi.org/10.1080/714000354.

Segers M., Nederland en de Europese integratie, in: De wereld volgens Nederland. Nederlandse buitenlandse politiek in historische perspectief, eds. J. Pekelder, R. Raben, M. Segers, Boom, Amsterdam 2015, pp. 83-106. Serfati S., Impérialisme et militarisme: actualité du XXIe siècle, Éditions Page Deux, Lausanne 2004. 
Smith M., Transatlantic security relations since the European security strategy: what role for the EU in its pursuit of strategic autonomy?, "Journal of European Integration", Vol. 40, No. 5/2018, pp. 605-620, DOI: https://doi.o $\mathrm{rg} / 10.1080 / 07036337.2018 .1488840$.

Stokes D., Trump, American hegemony and the future of the liberal international order, "International Affairs", Vol. 94, No. 1/2018, pp. 133-150, DOI: https://doi.org/10.1093/ia/iix238.

The EU and the European Security Strategy. Forging a global Europe, eds. S. Biscop, J.J. Andersson, Routledge, London and New York 2008, DOI: https://doi.org/10.4324/9780203945582.

The Military Planning and Conduct Capability (MPCC), November 2018, https://cdn4-eeas.fpfis.tech.ec.europa.eu/cdn/farfuture/aGKF41zrLDLuNeg8csm24scxmjEwj4JBvrRbaLeaY4M/mtime:1542656575/sites/ eeas/files/mpcc_factsheet_november_2018.pdf?fbclid=IwAR0aedfsd SDmzli6o7MuzWGeUl1 iuhunQvYbWeYzmcHBvDC53psf30XOWmw (access 24.09.2019).

Tocci N., The Demise of the International Liberal Order and the Future of the European Project, "Istituto Affari Internazionali", November 2018, http://www.iai.it/en/pubblicazioni/demise-international-liberal-orderand-future-european-project (access 24.09.2019).

Tocci N., The making of the EU Global Strategy, "Contemporary Security Policy", Vol. 37, No. 3/2016, pp. 461-472, DOI: https://doi.org/10.108 $0 / 13523260.2016 .1232559$.

Toje A., America, the EU and Strategic Culture. Renegotiating the Transatlantic Bargain, Routledge, London and New York 2008, DOI: https://doi. org/10.4324/9780203929704.

Ulrich B., 'Ihr langer Weg nach Trudering, ZEIT online, 31 May 2017, https://www.zeit.de/2017/23/angela-merkel-transatlantische-beziehungen-kritik-donald-trump (access 21.11.2017).

Webber M., NATO: the United States, transformation and the war in Afghanistan, "British Journal of Politics and International Relations", Vol. 11, No. 1/2009, pp. 46-63, DOI: https://doi.org/10.1111/j.1467-856x.2008.00349.x.

White Paper on the Future of Europe. Reflections and scenarios for the EU27 by 2025, March 2017, https://ec.europa.eu/commission/sites/betapolitical/files/white_paper_on_the_future_of_europe_en.pdf(access 24.11.2017).

Woodward B., Fear. Trump in the White House, Simon \& Schuster, London 2018.

Worth O., Beyond world order and transnational classes. The (re)application of Gramsci in global politics, in: Gramsci and global politics: hegemony and 
resistance, eds. M. McNally, J. Schwarzmantel, Routledge, London and New York 2009, pp. 19-31.

Worth O., Recasting Gramsci in international politics, "Review of International Studies", Vol. 37, No. 1/2011, pp. 373-392, DOI: https://doi. org/10.1017/S0260210510000318.

Wright T., A post-American Europe and the future of U.S. strategy, Brookings Report, December 2017, https://www.brookings.edu/research/a-postamerican-europe-and-the-future-of-u-s-strategy/ (access 24.11.2017). 